\title{
The factors affecting labour productivity in the construction of prestressed concrete buildings in Ghana
}

\author{
Muhammad Akbar', Kojo Kumah Darkwah², Azka Amin³, Pan Huali', Ou Guoqiang1, Muhammad Asghar ${ }^{4}$ \\ 1 Department of Engineering Institute of Mountain Hazards and Environment, Chinese Academy of Science, \\ Chengdu, China. \\ 2 School of Civil Engineering, Chang' an University, China. \\ 3 Iqra University, Karachi, Pakistan \\ 4 Yanshan University, Qinhuangdao, Hebei, China \\ * Correspondence: kojodarkwah@yahoo.com.: \\ Ph10902@126.com
}

\begin{abstract}
The construction industries face several challenges related to productivity. Productivity mainly depends upon labour effort and performance. The poor productivity of labour is one of the major reasons of time over-runs and increasing cost in construction projects. Our study aims to build a comprehensive assessment on the relationship between various factors that affect labour productivity in the construction of prestressed concrete Buildings in Ghana. A sample of 200 respondents collected from workers of Construction Company in Ghana. The questionnaire was designed which comprises two parts; the first part contains background information of the staff of construction company while second section explores the opinion of the staff regarding factors affecting labour productivity. The Smart-PLS was utilized to analyze and estimate the relationship among construct variables. By utilizing relative importance index and multiple linear regressions, it is identified that the management factor such as inadequate incentives; material factor such as poor quality of material; labour factors such as poor quality and training of labors; supervision factor such as incompetence of site supervisor; equipment factor such as frequent damage of equipment have a negative and significant relationship with labour productivity in the construction of prestressed concrete buildings in Ghana. The findings of this study recommend that in order to improve labour productivity, the construction industries must conduct labour productivity measurements by adopting schedule for procurement of materials, safety programs, motivational system, and frequent meeting with project professionals.
\end{abstract}

Keywords: Labour productivity; prestressed concrete floors; relative importance index (Smart-PLS. Ghana)

\section{Introduction}

The construction industry plays a vital and effective role in both developed and developing countries ([1-3], and considered as one of the most labour-intensive industries all over the world [4]; this is because it has a dynamic nature and easily relates to other sectors in the economy $[5,2,6]$. The construction industry plays a key role all over the world as it accounts for a large proportion of the country's total employment and makes a significant contribution to a country's overall income. For instance, $[5,7,8]$ reported that construction industry offers employment to people and a better quality of life to countries and positively associated with the success and progress of any economy. One of the most important factors affecting construction industry's growth is productivity and it is associated with the labour performance. Around the globe, productivity is considered as a dominant factor of construction industry as it promotes time, cost and efficient use of resources. 
Productivity mainly depends upon labour efforts and performance. According to [9] labour productivity plays a major role to determine the success of any construction industry. In most countries, labour cost accounts for $30 \%-50 \%$ of the total cost of a project [10]. Improving labour productivity is, therefore, a key concern for any industry that leads to increase profit which is the main objective for producer of any industry. Numerous factors have been examined to influence labour productivity in the construction industry. For instance, [11-12] pointed out that delaying in the payment of goods purchased by a company and the incompetency of the project manager affect labour productivity. Labour productivity is also influenced by the lack of financial incentive schemes and experienced and skill workers [13]. [14] have grouped five factors that affect labour productivity, namely, site and resource management factors; workforce characteristics factors; external factors; management factors and project characteristics factors. Therefore, labour productivity has been identified as one of the key significant factors influencing project performance in the construction industry in terms of time and cost. It also helps the industry to enhance its overall production, thereby contributing to boost economic growth of the country. As far as we know, no research yet has been conducted to examine the role of various other important factors such as management factors; material factors; design and technical factors; labour factors; supervision factors; equipment factors; policy, political and legal factors; environmental factors; and motivational factors on labour productivity.

Our interest in this subject is, thus, motivated by the neglected case of Ghana. The previous studies identified various factors affecting labour productivity for various countries [15-20, 9, 21-23]. Thus, the present study is, for the first time in the existing literature, to examine the nexus of factors affecting labour productivity in Ghana.

As a developing country of West Africa, with population of more than 23 million and land area covers 238,537 square kilometers; Ghana is one of the SSA countries where construction industry contributes significantly in promoting economic growth with increased foreign direct investment inflows, as it boosts the economic development of the country through generating employment opportunities [24-26]. The share of construction industry in GDP grew from 22\% in 2010 to 37\% in 2019 [13]. These statistics demonstrate the significant role of construction industry in promoting economic growth of the country.

On the basis of the findings of the study, our results contribute to the construction industry in Ghana by informing the parties of the negative and significant effect of factors that affect labour productivity. This could help them to save their time, production expenditures of construction projects, and mitigation of delays and stalled projects. Moreover, it is recommended that in order to communicate with employees and to minimize cost loss, the construction industry must train their management personnel. In addition, the labor force must be responsible for the work that has been completed, and at the same time must have the opportunity to improve labor skills.

We have organized the rest of the paper as follows. In Section 2, material and method are presented. Section 3 presents results and discussion, while section 4 concludes the whole study with policy recommendations and future research direction.

\section{Literature review}

The prestressed concrete buildings are different from the conventional structural engineering projects, mainly in the special issues that must be considered during, construction, installation, and operation. The prestressed concrete is the latest major building form introduced in structural engineering. Although a number of patents have been obtained for various prestressing schemes in the last century, they have not been successful due to the use of low-strength steel and low productivity. The designer provides a variety of structural system options for concrete frame buildings. They have choice to select from three basic available types; precast, cast in-situ, and hybrid construction. In concrete 
frame buildings, construction is considered the most time-consuming and expensive element [27-28].

Previously, several researchers investigated the factors affecting labour productivity of construction industry for both developed and developing countries. For instance, [29] examined 45 factors affecting labour productivity in Gaza Strip by dividing those factors into 10 major groups; (1) supervision, (2) materials/tools, (3) leadership, (4) quality, (5) time, (6) manpower, (7) project, (8) external, (9) motivation, and (10) safety. [30] investigated three categories responsible for affecting productivity on construction sites. The factors are characteristics of contractors, inadequate management strategy and organization's focus. Moreover, [31] identified four categories of the factors affecting productivity, these factors comprise (1) site, (2) management, (3) design, and (4) weather, while [32] presented two groups of influencing factors, (1) administrative and (2) administrative factors. Parallel to these studies, our paper fills the gap in the existing literature by investigating a wide range of factors such as, management factors; material factors; design and technical factors; policy, political and legal factors; equipment factors; environmental factors; motivational factors; supervision factors; and labour factors. (Table 1).

There exists a semi-compatibility of global classification scheme that can be used to categorize factors that affect labor productivity. Therefore, the researchers assumed the possibility of achieving that goal. These groups can keep their strength regardless of geographic location; although the effect of the factors may vary from country to country. Therefore, Table 1 demonstrates the list of factors that affect labour productivity both in developing and developed countries.

In contrast to the existing studies, our paper contributes to the literature by examining a wide range of factors such as, management factors; material factors; design and technical factors; policy, political and legal factors; equipment factors; environmental factors; motivational factors; supervision factors; and labour factors.

Table: 1 . Studies determine the factors influencing productivity in construction industry

\begin{tabular}{|c|c|c|c|c|c|c|c|c|c|c|c|}
\hline Authors & Country & $\begin{array}{l}\text { MAN } \\
\text { Factors }\end{array}$ & $\begin{array}{l}\text { MAT } \\
\text { Factors }\end{array}$ & $\begin{array}{l}\text { DES \& } \\
\text { TECH } \\
\text { Factors }\end{array}$ & $\begin{array}{l}\text { POLICY, } \\
\text { POLITICAL } \\
\text { \& LEG } \\
\text { Factors }\end{array}$ & $\begin{array}{l}\text { EQU } \\
\text { Factors }\end{array}$ & $\begin{array}{l}\text { ENV } \\
\text { Factors }\end{array}$ & $\begin{array}{l}\text { MOT } \\
\text { Factors }\end{array}$ & $\begin{array}{l}\text { SUP } \\
\text { Factors }\end{array}$ & $\begin{array}{l}\text { LAB } \\
\text { Factors }\end{array}$ & METHOD \\
\hline [33] & Egypt & NA & $\sqrt{ }$ & NA & $\checkmark$ & $\sqrt{ }$ & $\sqrt{ }$ & NA & $\sqrt{ }$ & $\sqrt{ }$ & $\begin{array}{l}\text { Survey } \\
\text { method } \\
\text { questionnaire }\end{array}$ \\
\hline [18] & Jordan & $\sqrt{ }$ & NA & NA & $\sqrt{ }$ & $\sqrt{ }$ & NA & NA & NA & NA & $\begin{array}{l}\text { Qualitative } \\
\text { approach }\end{array}$ \\
\hline [17] & Egypt & NA & $\sqrt{ }$ & NA & $\sqrt{ }$ & $\sqrt{ }$ & NA & NA & NA & $\sqrt{ }$ & $\begin{array}{l}\text { Survey } \\
\text { method } \\
\text { and RII }\end{array}$ \\
\hline [34] & Oman & NA & NA & NA & $\checkmark$ & NA & NA & NA & $\checkmark$ & $\sqrt{ }$ & SPSS \\
\hline [35] & Bahrain & NA & NA & $\sqrt{ }$ & $\sqrt{ }$ & NA & NA & NA & $\sqrt{ }$ & $\sqrt{ }$ & SPSS \\
\hline [36] & Pakistan & NA & NA & NA & $\sqrt{ }$ & NA & NA & NA & $\sqrt{ }$ & $\sqrt{ }$ & $\begin{array}{l}\text { Survey } \\
\text { method } \\
\text { \& RII }\end{array}$ \\
\hline [19] & Zimbabwe & NA & $\sqrt{ }$ & NA & $\sqrt{ }$ & $\sqrt{ }$ & NA & NA & $\sqrt{ }$ & $\sqrt{ }$ & $\begin{array}{l}\text { Qualitative } \\
\text { approach } \\
\text { \& RII }\end{array}$ \\
\hline
\end{tabular}




\begin{tabular}{|c|c|c|c|c|c|c|c|c|c|c|c|}
\hline [15] & Egypt & $\checkmark$ & $\sqrt{ }$ & & $\checkmark$ & NA & NA & $\sqrt{ }$ & $\sqrt{ }$ & $\sqrt{ }$ & $\begin{array}{l}\text { Survey } \\
\text { method }\end{array}$ \\
\hline [16] & Egypt & NA & NA & NA & $\sqrt{ }$ & NA & $\sqrt{ }$ & NA & $\sqrt{ }$ & $\sqrt{ }$ & $\begin{array}{l}\text { Survey } \\
\text { and RII }\end{array}$ \\
\hline [20] & India & NA & $\sqrt{ }$ & $\sqrt{ }$ & $\checkmark$ & NA & NA & NA & NA & NA & $\begin{array}{l}\text { Survey } \\
\text { Questionnaire }\end{array}$ \\
\hline [37] & USA & NA & $\sqrt{ }$ & $\sqrt{ }$ & NA & $\sqrt{ }$ & NA & NA & NA & NA & $\begin{array}{l}\text { Survey } \\
\text { and RII }\end{array}$ \\
\hline [38] & Libya & NA & $\checkmark$ & $\sqrt{ }$ & $\sqrt{ }$ & $\sqrt{ }$ & NA & $\sqrt{ }$ & NA & $\sqrt{ }$ & RII \\
\hline [36] & Chile & NA & $\sqrt{ }$ & $\sqrt{ }$ & $\checkmark$ & $\sqrt{ }$ & NA & NA & NA & NA & $\begin{array}{l}\text { Survey } \\
\text { Questionnaire }\end{array}$ \\
\hline [40] & USA & $\checkmark$ & $\sqrt{ }$ & $\sqrt{ }$ & $\checkmark$ & NA & NA & $\sqrt{ }$ & NA & NA & $\begin{array}{l}\text { Survey } \\
\text { method }\end{array}$ \\
\hline This Paper & Ghana & $\sqrt{ }$ & $\sqrt{ }$ & $\sqrt{ }$ & & $\checkmark$ & v & & $\checkmark$ & $\checkmark$ & $\begin{array}{l}\text { Survey } \\
\text { Questionnaire } \\
\text { \& Smart PLS }\end{array}$ \\
\hline
\end{tabular}

Note: MAN stands for management; MAT for material; DES \& TECH for design and technical; LEG for legal; EQU for equipment; ENV for environment; MOT for motivation; SUP for supervision; LAB for labour.

RII stands for Relative importance index

\section{Materials and Methods}

\subsection{Sample and measurement of scale}

The study utilized primary data collected from the staff of the construction industry through the administration of questionnaire (the questionnaire contained structured questions). The study utilized five points Likert-scale ( $1=$ strongly disagree to $5=$ strongly agree).The questionnaire was divided into two main parts (see Appendix A).

The first section comprises the background information of the staff of the construction company; however the second part explores the opinion of the staff on the factors affecting labour productivity in the construction of prestressed concrete floors. The factors were grouped into management; material; design and technical factors; supervision; labour; equipment; policy, political and legal; environmental and motivational factors. The demographic variables comprised a) gender, b) age group, c) marital status, d) job position, and e) length of service.

This study utilized a purposive sampling technique to acquire specific information from the participants mentioned below Table. 2 . The sample comprised of 450 questionnaires delivered among the people working in a construction company; among those 370 questionnaires received back. 200 questionnaires were fully completed out of the received questionnaires, while 170 contained missing information.

Table: 2. Demographic Table

\begin{tabular}{lll}
\hline Demographics variables & Frequency & Percent \\
\hline Gender & & \\
\cline { 1 - 1 } Male & 154 & 77 \\
Female & 46 & 23 \\
Age & & \\
\cline { 1 - 2 } & &
\end{tabular}




$\begin{array}{lll}18-25 & 72 & 0.36 \\ 26-30 & 54 & 0.27 \\ 31-35 & 43 & 0.21 \\ 36-40 & 31 & 0.16\end{array}$

\begin{tabular}{lll} 
Marital Status & & \\
\cline { 1 - 2 } unmarried & & 60 \\
Married & 73 & 36.5 \\
Divorce & 7 & 0.35
\end{tabular}

\begin{tabular}{lcl} 
Position & & \\
\cline { 1 - 2 } Labor & 176 & 0.88 \\
Engineer & 13 & 0.07 \\
Architecture & 11 & 0.05 \\
Tenure & & \\
\cline { 1 - 2 } $1-5$ & 123 & 0.61 \\
$6-10$ & 45 & 0.23 \\
$10-$-above & 32 & 0.16 \\
\hline
\end{tabular}

\subsection{Data analysis}

The Smart-PLS (3.3.3) software was used (Hair et al., 2016) to estimate the basic conceptual model. Furthermore, Smart-PLS (3.3.2) is employed to demonstrate the relationship between the construct variables [41]. The Smart-PLS is considered statistically reliable to explore the relationship between variables effectively. For practical assumptions, it is considered more flexible in terms of the data distribution where small sample size does not cause any type of identification issue.

Relative Important Index $=\frac{\sum_{\mathrm{i}=1}^{5} \mathrm{~W}_{\mathrm{i}}}{\mathrm{AxN}}$

Where $W i=$ the weight given to each factor by the respondents ranging from 1 to 5

$A=$ the highest weight $=5$

$N=$ the total number of respondents

Based on Equation (3.1) the relative importance index (RII) lies within 0 and 1.

The highest relative important index for each factor category was taken into the multiple linear regression. Multiple linear regression was used to assess the relationship between the independent variables and the dependent variable by fitting a linear model to the data collected. That is, to assess the effect of the factors on labour productivity, the multiple regression equation is given as

$$
\mathrm{LPi}=\alpha_{0}+\sum_{\mathrm{i}-1}^{\mathrm{n}} \alpha_{\mathrm{i}} \mathrm{ID}_{\mathrm{i}}+\varepsilon_{\mathrm{i}}
$$

Where $L P i=$ Dependent variable of unit and is, therefore, representing Labour Productivity of staff $i$.

$\alpha 0=$ the intercept 
$\alpha i=$ Coefficient of $i$.

$\mathrm{ID}_{\mathrm{i}}=$ Independent variable of factor category $\mathrm{i}$.

$\varepsilon_{i}=$ the error term.

Specifically, to assess the relationship between the independent variables (management factors (MAN), material factors (MAT), design and technical factors (DAN), labour factors (LAB), supervision factors (SUP), policy, political and legal factors (PPL), equipment factors (EQU), environmental factors (ENV), and motivational factors(MOT)) and labour productivity (LP), the multiple regression equation is given as;

$L P_{i}=\alpha_{o}+\alpha_{1} M A N_{i}+\alpha_{2} M A T_{i}+\alpha_{3} D A T_{i}+\alpha_{4} S U P_{i}+\alpha_{5} L A B_{i}+\alpha_{6} P P L_{i}+\alpha_{7} E Q U_{i}+\alpha_{8} E N V_{i}+\alpha_{9} M O T_{i}+$

$\varepsilon_{i}$

Where $\mathrm{Y}=$ labour productivity (dependent variable); $\mathrm{X}$ =factor category (independent variables); $\alpha$ \& $\beta=$ unknown constants; $\varepsilon=$ random error for any set of values.

The description of all variables is presented in Table B1 in Appendix B.

\section{Discussion and Findings}

The study assessed various factors (management factors, material factors, design, and technical factors, labour factors, supervision factors, policy, political and legal factors, equipment factors, environmental factors, and motivational factors) affecting labour productivity in the construction of prestressed concrete buildings in the Greater Accra Region of Ghana.

Table 3 presents the mean values, standard deviation, minimum and maximum values of output, total working time, and labour productivity. From Table 3, output in a day has a mean of 85.5 square feet and a standard deviation of 2.5 square feet. This means that, on average, the respondent work on 85.5 square feet of prestressed concrete floors in a day. The total working time in a day has a mean of 6.2 hours and a standard deviation of 1.8 hours. This means that on average the respondent works 6.2 hours when constructing prestressed concrete floors daily. The mean and standard deviation of labour productivity is 13.790 sq feet/hour and 1.389 sq feet/hour respectively. This means that, on average, the total output of labour over the working hour is $13.790 \mathrm{sq}$ feet/hour. The Shapiro-Wilk test for assessing the normality of labour productivity found that labour productivity was normally distributed.

Table 3: Summary Statistics of Labour Productivity

\begin{tabular}{llllll}
\hline Mean & SD & $\begin{array}{l}\text { Min } \\
\text { value }\end{array}$ & $\begin{array}{l}\text { Max } \\
\text { value }\end{array}$ & $\begin{array}{l}\text { Shapiro-Wilk } \\
\text { Test }\end{array}$ & P-value \\
\hline 6.2 & 1.8 & 4.8 & 9 & 0.81 & 0.712 \\
85.5 & 2.5 & 40 & 225 & 0.972 & 0.139 \\
13.79 & 1.389 & 8.333 & 25 & 0.946 & 0.81 \\
\hline
\end{tabular}

Table 4 provides the pairwise correlation coefficients for the factors that influence labor productivity. In Table 4, it is obvious that the values of all correlation coefficients are less than 0.5, which depicts absence of multicollinearity. Also, the study utilized the correlation analysis to investigate the strength of association between the factor categories (such as management factors, material factors, design and technical factors, 
labour factors, supervision factors, policy, political and legal factors, equipment factors, environmental factors, motivational factors and labour productivity).

Table 4: Pearson Bivariate Correlation Coefficient

\begin{tabular}{|c|c|c|c|c|c|c|c|c|c|c|}
\hline & LAP & MAN & MAT & LAB & SUP & PPL & DAT & EQU & ENV & MOT \\
\hline LAP & 1 & & & & & & & & & \\
\hline MAN & -0.016 & 1 & 10.02 & 0.153 & 0.139 & 0.098 & 0.028 & 0.046 & 0.061 & 0.017 \\
\hline MAT & -0.028 & 0.02 & 1 & - & - & - & - & - & - & - \\
\hline LAB & -0.139 & -0.095 & -0.028 & 1 & - & - & - & - & - & - \\
\hline SUP & -0.153 & -0.06 & 0.093 & 0.073 & 1 & - & - & - & - & - \\
\hline PPL & -0.046 & 0.141 & -0.022 & 0.179 & -0.019 & 1 & - & - & - & - \\
\hline DAT & -0.098 & -0.04 & -0.127 & -0.145 & 0.023 & 0.113 & 1 & - & - & - \\
\hline EQU & -0.061 & -0.047 & 0.019 & 0.117 & -0.175 & -0.051 & -0.164 & 1 & - & - \\
\hline ENV & -0.017 & 0.037 & -0.052 & -0.037 & 0.056 & -0.113 & -0.183 & -0.094 & 1 & - \\
\hline MOT & -0.076 & -0.016 & -0.038 & -0.086 & -0.122 & -0.012 & 0.103 & -0.251 & -0.191 & 1 \\
\hline
\end{tabular}

Table 5 presents the results of Cronbach's Alpha. As Cronbach Alpha is used to test the construct reliability of the items of each factor category as recommended by [42-43]. The reliability test evaluated using the value of Cronbach Alpha should be greater than 0.70 for a good scale [42]. The reliability coefficients in Table 5 are between 0.70 to 0.90 which is accepted as suggested by [42-43]. Hence, this shows that the items of each of the factor category affecting labour productivity are reliable

Table 5: Results of Reliability Test: Cronbach's Alpha

\begin{tabular}{ll}
\hline Factor Category & Cronbach's Alpha \\
\hline Management (MAN) & 0.814 \\
Material (MAT) & 0.913 \\
Design and Technical (DAT) & 0.812 \\
Labour (LAB) & 0.879 \\
Supervision (SUP) & 0.861 \\
Policy, Political and Legal (PPL) & 0.701 \\
(Equipment EQU) & 0.793 \\
Environmental (ENV) & 0.826 \\
Motivational (MOT) & 0.904 \\
\hline
\end{tabular}

The study used multiple linear regression to assess the factors influencing labour productivity in the construction of prestressed concrete floors. The item with the highest relative important index (RII) of each factor category was used as a proxy for that category. Before evaluating the factors affecting labour productivity, the study used the Durbin Watson (DW) test to check the presence of autocorrelation and Variance Inflation Factor (VIF) statistics in order to check the presence of multicollinearity in the data.

From Table 6, it is obvious that value of R2 (coefficient of determination) is 0.839 . This shows that $83.9 \%$ variation in labour productivity is explained by the independent variables (management factors, material factors, design and technical factors, labour factors, supervision factors, policy, political and legal factors, equipment factors, environmental factors, and motivational factors). The value of the Durbin Watson (DW) 
statistic is 1.792 which shows the presence of no autocorrelation, since the value lies between the two critical values of $1.5<\mathrm{DW}<2.5$ [44]. Thus, Table 5 shows that model is perfect and best fitted.

Table 6: Model Summary

\begin{tabular}{llll}
\hline $\mathbf{R}^{2}$ & Adjusted $\mathbf{R}^{2}$ & SE & DW \\
\hline 0.839 & 0.831 & 0.863 & 1.792 \\
\hline
\end{tabular}

Note: SE stands for standard error. DW stands for Durbin-Watson.

Table 7 shows the Analysis of Variance results that is used to assess the significance of R2. The F-test shows the overall fitness of the model. The null hypothesis of the F-test depicts that there exist no linear relationship between independent and dependent variables. From Table 6, the independent variables significantly influence the dependent variable, F-value $(9,190)=4.330, \mathrm{p}<0.000$. Hence, the F-test approves the strength of the contribution of the independent variables to affect dependent variable in the construction of prestressed concrete buildings in Ghana.

Table 7: Analysis of Variance

\begin{tabular}{lllll}
\hline Model & Sum of Squares & Df & Mean Square & F-value \\
\hline Regression & 4.361 & 9 & 0.485 & $4.330^{* * *}$ \\
Residual & 21.268 & 190 & 0.112 & - \\
Total & 25.629 & 199 & - & - \\
\hline
\end{tabular}

Note: ${ }^{* * *}$ shows significance level at $10 \%$.

Table 8 shows the multiple linear regression analysis that is used to examine the factors affecting labour productivity. From Table 7, it is obvious that the variance inflation factor (VIF) is within the boundary. The lowest and highest VIF values range between 1.136 to 1.541 [44].

The coefficient of each factor demonstrates that how dependent variable affects from the independent variables. The management factor category (MAN) has a negative and significant relationship with labour productivity in the construction of prestressed concrete floors. This suggests that lack/inadequate incentives (used as a proxy for the management factor category) negatively affect labour productivity. Our findings are consistent with [45-47], they identified that poor site management which includes poor supervision of team members or team members not supervised at all affects the productivity of the labour. The material factor category (MAT) shows negative and significant relationship with labour productivity. The coefficient value demonstrates that $1 \%$ increase in the poor quality material (used as a proxy of material factor) leads to decrease labour productivity by $0.094 \%$. The coefficient of labour factor category (LAB) shows that poor performance and bad training of labours leads to decrease labour productivity.

The negative coefficient of supervision factor category (SUP) suggests that the incompetence of the site supervisor negatively affects labour productivity. Our findings are similar with $[2,48,35,15,49]$. They found that unskilled workers mostly produce lower output, which is the reason; their output is mostly rejected by their supervisors. The unskilled and inexperience labour in the construction on prestressed concrete floors is the major cause of all failed and delayed projects. Most construction of prestressed concrete floors are requesting for labour that have experience in bar tender, mixer operators and mixer vibrators but most of the applicants do not have enough experience and skills when employed and need to spend time to learn which affects the productivity of the company. The equipment factor category (EQU) depicts that the poor quality of equipment negatively affects labour productivity. Our results are consistent with the findings 
reported by $[50,19,22]$. Their results showed that unavailability of plants and equipment are the key factors that negatively affect labour productivity. They further pointed out that without enough equipments and machinery, labour cannot perform their duties efficiently. The negative and significant coefficient of motivational factor category (used as a proxy for the motivational factor category) demonstrates that delay in wages leads to decrease labour productivity. The negative coefficient value demonstrates that 1 unit increase in motivational factors (delay in wages of workers) leads to decrease labour productivity by 0.309 units. Our results are similar with the finding reported by [51]. According to [51], a strong motivation among labour leads to enhance their overall productivity. A company can be successful by satisfying its employees.

Table 8: Regression Analysis Results

\begin{tabular}{llllll}
\hline Model & Unstandardized & Coefficients & t-stat & Significance & Statistic \\
\hline & Coefficient & Std. Error & & & VIF \\
Constant & 0.159 & 0.182 & 0.874 & 0.384 & \\
Management (MAN) & -0.143 & 0.062 & -2.306 & $0.018^{* *}$ & 1.062 \\
Material (MAT) & -0.094 & 0.019 & -2.306 & $0.027^{* *}$ & 1.044 \\
Design and Technical (DAT) & -0.036 & 0.079 & -1.921 & 0.057 & 1.074 \\
Labour (LAB) & -0.238 & 0.037 & -3.013 & $0.002^{* *}$ & 1.065 \\
Supervision (SUP) & -0.279 & 0.104 & -2.683 & $0.013^{* *}$ & 1.015 \\
Policy, Political and Legal & -0.013 & 0.072 & -1.431 & 0.062 & 1.061 \\
(PPL) & & & & & 1.035 \\
(Equipment EQU) & -0.124 & 0.047 & -2.638 & $0.000^{* *}$ & 1.08 \\
Environmental (ENV) & -0.112 & 0.102 & -1.098 & 0.138 & 1.027 \\
Motivational (MOT) & -0.309 & 0.136 & -2.272 & 0.005 & \\
\hline
\end{tabular}

Note: ${ }^{* *}$ shows $5 \%$ significance level.

\section{Conclusions policy recommendations}

The construction industry faces productivity-related issues, which are mainly the result of labor productivity. In order to boost labour productivity in construction industry, the influence of various factors that helps to improve labour productivity needs to be identified. The objective of this study is to investigate the impact of nine different factors (such as, management factors; material factors; design and technical factors; labour factors; equipment factors; policy, political and legal factors; supervision factors; environmental factors and motivational factors) on labour productivity and identify the efficiency of these factors in construction industry. The purposive sampling is utilized to select 200 participants using structured questionnaires. It is concluded that factors, such as, management factor, material factor, labour factors, supervision factor, equipment factor and motivational factor have a negative and significant relationship with labour productivity in the construction of prestressed concrete buildings in Ghana.

On the basis of the results reported in this study, our results contribute to the construction industry in Ghana by helping project contractors to save their time, production expenditures of construction projects, and mitigation of delays and stalled projects. Furthermore, it is recommended that the construction industry must train their management personnel in order to minimize production loss. Besides, the workers must be responsible for their duties, and at the same time they must provide opportunities and trainings to improve their labor skills.

By employing appropriate estimation technique, the findings of this study are found robust and reliable. Based on the empirical results, it is recommended that, 
- The management of the construction companies engaged in the construction of prestressed concrete floor should provide incentive scheme for overtime work, or they must conduct annual review of existing available incentive schemes.

- There should be weekly services of equipment and the purchase of quality equipment from recognized companies. They should ensure timely payment of wages to labourers to motivate them to work effectively.

- The human resource managers of the construction companies should provide proper in-service training to workers newly recruited or ensure that qualified and experienced workers are employed.

In the future, this study can be extended to examine the labour productivity influences the financial performance of construction companies. Also, investigate whether contract management strategies mediate the relationship between labour productivity and the financial performance of the construction company.

In view of the numerous factors that affect labor productivity, this study provides a basis for improving the labor productivity of pre-stressed in construction system in the future. Further, it is expected that while taking into account the difficulties encountered in this research, future research will improve the techniques used in this study.

Table 9: Mean, Standard Deviation, and Relative Importance Index of Factors

\begin{tabular}{|c|c|c|c|}
\hline Factors & Mean & SD & $\begin{array}{l}\text { Relative } \\
\text { Importance } \\
\text { Index }\end{array}$ \\
\hline The level of management control & 4.427 & 1.061 & 0.913 \\
\hline Professionalism of the design team. & 4.38 & 1.091 & 0.864 \\
\hline Difficulties with recruitment of site supervisors & 4.571 & 0.96 & 0.943 \\
\hline Work planning and scheduling & 4.344 & 1.089 & 0.812 \\
\hline Indiscipline labour & 4.316 & 1.095 & 0.719 \\
\hline Bad resource management & 4.421 & 1.039 & 0.916 \\
\hline Difficulty with recruitment of workers & 4.493 & 1.033 & 0.927 \\
\hline Lack of incentives & 4.925 & 0.935 & 0.985 \\
\hline Away from location of material storage & 4.411 & 0.869 & 0.717 \\
\hline Shortage of construction material in market & 4.398 & 0.915 & 0.703 \\
\hline Delay in material delivery & 4.608 & 0.862 & 0.854 \\
\hline Change in material type and specifications during construction & 4.472 & 0.854 & 0.728 \\
\hline Poor quality material & 4.635 & 0.844 & 0.894 \\
\hline Design changes & 4.412 & 0.984 & 0.561 \\
\hline Incomplete drawing & 4.579 & 0.975 & 0.67 \\
\hline Inaccurate design & 4.702 & 0.912 & 0.817 \\
\hline Delay in approving drawings & 4.696 & 0.93 & 0.783 \\
\hline Mistake and discrepancies in design documents & 4.689 & 0.938 & 0.757 \\
\hline Repetition and complexity & 4.678 & 0.978 & 0.72 \\
\hline Supervisor absenteeism & 4.799 & 0.859 & 0.884 \\
\hline Unclear instructions to labour & 4.742 & 0.887 & 0.867 \\
\hline
\end{tabular}




\begin{tabular}{|c|c|c|c|}
\hline No supervision method & 4.738 & 0.905 & 0.865 \\
\hline Late inspection of completed work & 4.713 & 0.924 & 0.858 \\
\hline Incompetence of site supervisor & 4.825 & 0.835 & 0.927 \\
\hline Rework & 4.789 & 0.876 & 0.871 \\
\hline poor quality training and experience of labour & 4.809 & 0.875 & 0.942 \\
\hline disturbance by labourers & 4.701 & 0.982 & 0.681 \\
\hline use of alcohol and drugs & 4.768 & 0.915 & 0.813 \\
\hline frequent changes in labours & 4.708 & 0.979 & 0.684 \\
\hline Communication problems in labours & 4.761 & 0.933 & 0.927 \\
\hline Turnover of labour & 4.753 & 0.95 & 0.871 \\
\hline High absenteeism of labours & 4.775 & 0.902 & 0.942 \\
\hline Delay in arrival of equipment & 4.496 & 0.818 & 0.681 \\
\hline Frequent damage of equipment & 4.581 & 0.806 & 0.813 \\
\hline Shortage of equipment parts & 4.374 & 0.844 & 0.684 \\
\hline Equipment availability & 4.321 & 0.856 & 0.803 \\
\hline Poor quality of equipment & 4.478 & 0.842 & 0.788 \\
\hline Instability in governance & 2.316 & 0.604 & 0.864 \\
\hline Political agitation & 2.394 & 0.62 & 0.787 \\
\hline Political instability & 2.981 & 0.686 & 0.865 \\
\hline Legislation & 2.945 & 0.73 & 0.509 \\
\hline Election & 2.518 & 0.632 & 0.404 \\
\hline Planning regulation & 2.967 & 0.709 & 0.519 \\
\hline Types of contract & 2.96 & 0.719 & 0.514 \\
\hline Attitude of judiciary & 2.01 & 0.529 & 0.254 \\
\hline Natural disaster (fire, storm, land slide) & 4.802 & 0.874 & 0.861 \\
\hline Unfavorable site conditions & 4.786 & 0.89 & 0.845 \\
\hline Unexpected geological conditions & 4.787 & 0.9 & 0.838 \\
\hline \multirow[t]{2}{*}{ Climate condition/bad weather (rain, heat etc.) } & 4.811 & & 0.874 \\
\hline & & 0.856 & \\
\hline Delay in wage & 4.891 & 0.822 & 0.969 \\
\hline Lack of financial motivation & 4.802 & 0.86 & 0.937 \\
\hline \multirow{2}{*}{$\begin{array}{c}\text { Lack of labour recognition programs } \\
\mathbf{A} \\
\mathbf{u}\end{array}$} & 4.886 & & 0.954 \\
\hline & & 0.836 & \\
\hline Non-provision $\mathbf{t}_{\mathrm{of}}$ transportation & 4.573 & 0.887 & 0.697 \\
\hline Lack of places for eating and relaxation & 4.569 & 0.905 & 0.69 \\
\hline
\end{tabular}

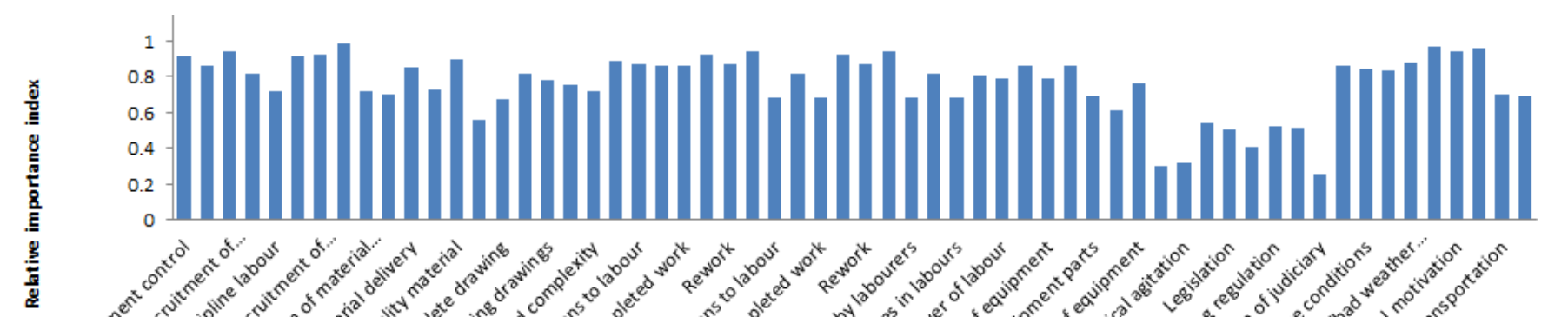


Contributions: Conceptualization, M.A. and K.K.; methodology, M.A.; software, K.K.; and M.A validation, M.A., K.K. and P.H.; formal analysis, M.A.; investigation, K.K.; resources, M.A.; data curation, K.K.; writing-original draft preparation, M.A.; and K.K and P.H writing-review and editing, A.A.; and M,A visualization, M.A.; supervision, P.H.; and O.G project administration, P.H.; funding acquisition, M.A. All authors have read and agreed to the published version of the manuscript.

Funding: This paper was supported by theSecond Tibetan Plateau Scientific Expedition and Research Program (STEP), (Grant No. 2019QZKK0902) and National Natural Science Foundation of China (Grant No. 42077275). It was also supported by Youth Innovation Promotion Association of the Chinese Academy of Sciences (2018405).

Data Availability Statement: Data will be provided from corresponding author on demand.

Acknowledgments: The authors would like to acknowledge Institute of Mountain Hazards Environment, Chinese Academy of Sciences, Chengdu, China for providing us the platform to conduct this valuable research.

Conflicts of Interest: The authors declare no conflict of interest.

\section{Appendix A}

\section{SECTION A: BACKGROUND INFORMATION}
- Gender
(a). Male [ ]
(b). Female 
- $\quad$ Age group (a). 18-25 years [ ] (b). 26-30 years [ ] (c). 31-35 years [ ] (d). 36-40 years and above [ ]

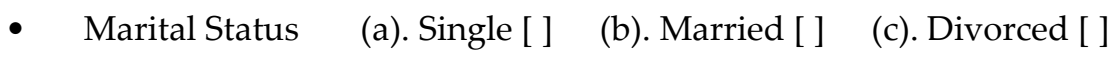

- Job Position (a). Engineer [ ] (b). Architecture [ ] (c). Laborer [ ] (d). Mason [ ]

- $\quad$ Length of service (a). Below 1 year [ ] (b). 1-5 years [ ] (c). 6-9 years [ ] (d). 10 years and above [ ]

\section{Appendix B}

Listed below is series of factors (management; material; design and technical; supervision; labour; equipment; policy, political and legal; environmental; and motivational factors) With respect to your own point of view, please indicate the degree of your agreement or disagreement with each statement by marking.

Strongly disagree (1) disagree (2) neutral (3) agree (4) and strongly agree (5).

Table B1: Table B1. Factors affecting labour productivity

\begin{tabular}{llllll}
\hline Part A. Management Factors & NI & LI & I & MI & MOI \\
\hline & F (\%) & F (\%) & F (\%) & F (\%) & F (\%) \\
$\begin{array}{l}\text { The level of management control } \\
\text { Professionalism of the design }\end{array}$ & $0(0.0)$ & $0(0.0)$ & $0(0.0)$ & $87(43.5)$ & $113(56.5)$ \\
team. & $0(0.0)$ & $0(0.0)$ & $0(0.0)$ & $136(68.0)$ & $64(32.0)$ \\
Difficulties with recruitment of & & & & & \\
site supervisors & $0(0.0)$ & $0(0.0)$ & $0(0.0)$ & $57(28.5)$ & $143(71.5)$ \\
Work planning and scheduling & $0(0.0)$ & $0(0.0)$ & $47(23.5)$ & $94(47.0)$ & $59(29.5)$ \\
Indiscipline labour & $0(0.0)$ & $0(0.0)$ & $96(48.0)$ & $89(44.5)$ & $15(7.5)$ \\
Bad resource management & $0(0.0)$ & $0(0.0)$ & $0(0.0)$ & $84(42.0)$ & $116(58.0)$ \\
Difficulty with recruitment of & & & & & \\
workers & $0(0.0)$ & $0(0.0)$ & $0(0.0)$ & $73(36.5)$ & $127(63.5)$ \\
Lack of incentives & $0(0.0)$ & $0(0.0)$ & $0(0.0)$ & $15(7.5)$ & $185(92.5)$
\end{tabular}

Part B. Material factors

Away from location of material storage

$0(0.0) \quad 0(0.0)$

97 (48.5)

89 (44.5)

$14(7.0)$

Shortage of construction material

in market

$0(0.0) \quad 0(0.0)$

$112(56.0) \quad 73(36.5)$

15(7.5)

Delay in material delivery

$0(0.0)$

$0(0.0)$

$0(0.0)$

146 (73.0)

54(27.0)

Change in material type and

specifications during construc-

tion

$0(0.0) \quad 0(0.0)$

107(53.5)

58 (29.0)

35(17.5)

Poor quality material

$0(0.0)$

$0(0.0)$

$0(0.0)$

106 (53.0)

94(47.0)

Part C. Design and technical fac-

tors

Design changes

$34(17.0)$

$48(24.0)$

$57(28.5)$

$45(22.5)$

$16(8.0)$

Incomplete drawing

$18(9.0) \quad 32(16.0) \quad 38(19.0) \quad 86(43.0) \quad 26(13.0)$




\begin{tabular}{|c|c|c|c|c|c|}
\hline Inaccurate design & $0(0.0)$ & $0(0.0)$ & $66(33.0)$ & $51(25.5)$ & $83(41.5)$ \\
\hline Delay in approving drawings & $0(0.0)$ & $9(4.5)$ & $51(25.5)$ & $88(44.0)$ & $52(26.0)$ \\
\hline \multicolumn{6}{|l|}{ Mistake and discrepancies in } \\
\hline design documents & $0(0.0)$ & $0(0.0)$ & $92(46.0)$ & $59(29.5)$ & $49(24.5)$ \\
\hline Repetition and complexity & $0(0.0)$ & $0(0.0)$ & $101(50.5)$ & $78(39.0)$ & $21(10.5)$ \\
\hline \multicolumn{6}{|l|}{ Part D. Supervision factors } \\
\hline Supervisor absenteeism & $0(0.0)$ & $0(0.0)$ & $0(0.0)$ & $116(58.0)$ & $84(42.0)$ \\
\hline Unclear instructions to labour & $0(0.0)$ & $0(0.0)$ & $0(0.0)$ & $133(66.5)$ & $67(33.5)$ \\
\hline No supervision method & $0(0.0)$ & $0(0.0)$ & $0(0.0)$ & $135(67.5)$ & $65(32.5)$ \\
\hline \multicolumn{6}{|l|}{ Late inspection of completed } \\
\hline work & $0(0.0)$ & $0(0.0)$ & $0(0.0)$ & $142(71.0)$ & $58(29.0)$ \\
\hline Incompetence of site supervisor & $0(0.0)$ & $0(0.0)$ & $0(0.0)$ & $73(36.5)$ & $127(63.5)$ \\
\hline Rework & $0(0.0)$ & $0(0.0)$ & $0(0.0)$ & $129(64.5)$ & $71(35.5)$ \\
\hline \multicolumn{6}{|l|}{ Part E. Labour factors } \\
\hline \multicolumn{6}{|l|}{ poor quality training and expe- } \\
\hline rience of labour & $0(0.0)$ & $0(0.0)$ & $0(0.0)$ & $58(29.0)$ & 142(71.0) \\
\hline disturbance by labourers & $0(0.0)$ & $37(18.5)$ & $72(36.0)$ & $64(32.0)$ & $27(13.5)$ \\
\hline use of alcohol and drugs & $0(0.0)$ & $0(0.0)$ & $43(21.5)$ & $101(50.5)$ & $56(28.0)$ \\
\hline frequent changes in labours & $0(0.0)$ & $0(0.0)$ & $124(62.0)$ & $68(34.0)$ & $8(4.0)$ \\
\hline \multicolumn{6}{|l|}{ Communication problems in } \\
\hline labours & $0(0.0)$ & $0(0.0)$ & $52(26.0)$ & $93(46.5)$ & $55(27.5)$ \\
\hline Turnover of labour & $0(0.0)$ & $0(0.0)$ & $78(39.0)$ & $56(28.0)$ & $66(33.0)$ \\
\hline High absenteeism of labours & $0(0.0)$ & $0(0.0)$ & $21(10.5)$ & $94(47.0)$ & $85(42.5)$ \\
\hline \multicolumn{6}{|l|}{ Part F. Equipment factors } \\
\hline Delay in arrival of equipment & $0(0.0)$ & $0(0.0)$ & $61(30.5)$ & $91(45.5)$ & $48(24.0)$ \\
\hline Frequent damage of equipment & $0(0.0)$ & $0(0.0)$ & $0(0.0)$ & $135(67.5)$ & $65(32.5)$ \\
\hline Shortage of equipment parts & $0(0.0)$ & $0(0.0)$ & $131(65.5)$ & $49(24.5)$ & $20(10.0)$ \\
\hline Equipment availability & $0(0.0)$ & $57(28.5)$ & $82(41.0)$ & $55(27.5)$ & $6(3.0)$ \\
\hline Poor quality of equipment & $0(0.0)$ & $0(0.0)$ & $67(33.5)$ & $107(53.5)$ & $26(13.0)$ \\
\hline \multicolumn{6}{|l|}{ Part G. Policy, political and legal } \\
\hline \multicolumn{6}{|l|}{ factors } \\
\hline Instability in governance & $132(66.0)$ & $35(17.5)$ & $33(16.5)$ & $0(0.0)$ & $0(0.0)$ \\
\hline Political agitation & $79(39.5)$ & $121(60.5)$ & $0(0.0)$ & $0(0.0)$ & $0(0.0)$ \\
\hline Political instability & $0(0.0)$ & $58(29.0)$ & $142(71.0)$ & $0(0.0)$ & $0(0.0)$ \\
\hline Legislation & $0(0.0)$ & $91(45.5)$ & $109(54.5)$ & $0(0.0)$ & $0(0.0)$ \\
\hline Election & $59(29.5)$ & $78(39.0)$ & $63(31.5)$ & $0(0.0)$ & $0(0.0)$ \\
\hline Planning regulation & $0(0.0)$ & $81(40.5)$ & $119(59.5)$ & $0(0.0)$ & $0(0.0)$ \\
\hline Types of contract & $0(0.0)$ & $86(43.0)$ & $114(57.0)$ & $0(0.0)$ & $0(0.0)$ \\
\hline Attitude of judiciary & $146(73.0)$ & $54(27.0)$ & $0(0.0)$ & $0(0.0)$ & $0(0.0)$ \\
\hline \multicolumn{6}{|l|}{ Part H. Environmental factors } \\
\hline \multicolumn{6}{|l|}{ Natural disaster (fire, storm, land } \\
\hline slide) & $0(0.0)$ & $0(0.0)$ & $0(0.0)$ & $139(69.5)$ & $61(30.5)$ \\
\hline Unfavorable site conditions & $0(0.0)$ & $0(0.0)$ & $0(0.0)$ & $155(77.5)$ & $45(22.5)$ \\
\hline
\end{tabular}




\begin{tabular}{llllll}
$\begin{array}{l}\text { Unexpected geological conditions } \\
\text { Climate condition/bad weather }\end{array}$ & $0(0.0)$ & $0(0.0)$ & $0(0.0)$ & $162(81.0)$ & $38(19.0)$ \\
(rain, heat etc.) & $0(0.0)$ & $0(0.0)$ & $0(0.0)$ & $126(63.0)$ & $74(37.0)$ \\
$\begin{array}{l}\text { Part I. Motivational factors } \\
\text { Delay in wage }\end{array}$ & $0(0.0)$ & $0(0.0)$ & $0(0.0)$ & $31(15.5)$ & $169(84.5)$ \\
Lack of financial motivation & $0(0.0)$ & $0(0.0)$ & $0(0.0)$ & $63(31.5)$ & $137(68.5)$ \\
Lack of labour recognition pro- & & & & & \\
grams & $0(0.0)$ & $0(0.0)$ & $0(0.0)$ & $46(23.0)$ & $154(77.0)$ \\
Non-provision of transportation & $0(0.0)$ & $0(0.0)$ & $118(59.0)$ & $67(33.5)$ & $15(7.5)$ \\
Lack of places for eating and & & & & & \\
relaxation & $0(0.0)$ & $0(0.0)$ & $131(65.5)$ & $48(24.0)$ & $21(10.5)$ \\
\hline
\end{tabular}

$\mathrm{NI}=$ Not Important, LI= Less Important, I= Important, MI= More Important, MOI = Most Important

\section{References}

1. Nasirzadeh, F., Rostamnezhad, M., Carmichael, D.G., Khosravi, A., Aisbett, B. Labour productivity in Australian building construction projects: a roadmap for improvement. International journal of construction management 2020 https://doi.org/10.1080/15623599.2020.1765286

2. Alaghbari, W.; Al-Sakkaf, A.A.; Sultan, B. Factors affecting construction labour productivity in Yemen. International journal of construction management 2019, 19(1), 79-91. https://doi.org/10.1080/15623599.2017.1382091

3. Naoum, S.G. Factors influencing labor productivity on construction sites: A state-of-the-art literature review and a survey. International Journal of Productivity and Performance Management 2016 65(3): 401-421.

https://doi.org/10.1108/IJPPM-03-2015-0045

4. Ghodrati, N., Yiu, T.W., Wilkinson, S. Unintended consequences of management strategies for improving labour productivity in construction industry. J Safety Res 201867 107-116. https://doi.org/10.1016/j.jsr.2018.09.001

5. Momade, M.H., Shahid, S., Hainin, M.H.R.B., Nashwan, M.S., Umar, A.T. Modelling labour productivity using SVM and RF: a comparative study on classifiers performance. International Journal of Construction Management 2020 https://doi.org/10.1080/15623599.2020.1744799

6. Dixit, S., Pandey, A.K., Mandal, S.N., Bansal, S. A study of enabling factors affecting construction productivity: Indian scnerio. International Journal of Civil Engineering \& Technology 2017 8(6), 741-758.

7. Selvam, G., Madhavi, T.C., Begum, T.P.N., Sudheesh, M. Impact of labour productivity in estimating the duration of construction projects. International Journal of Construction Management 2020.

8. Lopes, J., Oliveira, R., Abreu, M. The Sustainability of the Construction Industry in Sub-Saharan Africa: some new evidence from recent data. Procedia Engineering 2017 172, 657-664. http://doi.org/doi:\%2010.1016/j.proeng.2017.02.077

9. Mahamid, I.A., Al-Ghonamy, A., Aichouni, M. Major factors influencing employee productivity in the KSA public construction projects. International journal of civil and environmental engineering 2013 14(1), 16-20.

10. Guhathakurta S., Yates J. International Labour Productivity. Journal of Cost Engineering, 1993 35 (1), 15-25.

11. Jarkas, A.M., Radosavljevic, M., Wuyi, L. Prominent demotivational factors influencing the productivity of construction project managers in Qatar. International Journal of Productivity and Performance Management 2014 63(8), 1070-1090. https://doi.org/10.1108/IJPPM-11-2013-0187

12. Gudienè, N., Banaitis, A., Banaitienè, N. Evaluation of critical success factors for construction projects-an empirical study in Lithuania. International journal of strategic property management 2012 17(1), 21-31. https://doi.org/10.3846/1648715X.2013.787128

13. Ministry of Roads and Highways. Medium Term Expenditure Framework (Mtef) 2020.

14. Gopal, S.R., Murali, K. Analysis of Factors affecting Labour Productivity in Construction. International Journal of Recent Scientific Research 2012 7(6), 11744-11747.

15. El-Gohary, K.M., Aziz, R.F. Factors influencing construction labor productivity in Egypt. J Manage Eng 2014 30(1), 1-9. https://doi.org/10.1061/(ASCE)ME.1943-5479.0000168

16. Hafez, S.M., Aziz, R.F., Morgan, E.S., Abdullah, M.M., Ahmed, E.K. Critical factors affecting construction labor productivity in Egypt. American Journal of Chemical Engineering 2014 2(2), 35-40.

17. Gerges, M., Ahiakwo, O., Aziz, R., Kapogiannis, G., Saidani, M., Saraireh, D. Investigating and ranking labor productivity factors in the Egyptian Construction Industry. International Journal of Architecture, Engineering and Construction 2016 5(1), 44-52. http://dx.doi.org/10.7492/IJAEC.2016.005 
18. Hiyassat, M.A., Hiyari, M.A., Sweis, G.J. Factors affecting construction labour productivity: a case study of Jordan. International Journal of Construction Management 2016 16(2), 138-149. https://doi.org/10.1080/15623599.2016.1142266

19. Chigara, B.A., Moyo, T. Factors Affecting Labor Productivity on Building Projects in Zimbabwe. International Journal of Architecture, Engineering and Construction 2014, 3(1), 57-65. http://doi.org/10.7492/I]AEC.2014.005

20. Thomas, A.V., Sudhakumar, J. Factors influencing construction labour productivity: an Indian case study. Journal of Construction in Developing Countries 2014 19(1), 53-68.

21. Alinaitwe, H.M., Mwakali, J.A., Hansson, B. Factors affecting the productivity of building craftsmen-studies of Uganda. J Civ Eng Manag 2007, 13(3), 169-176

22. Makulsawatudom, A., Emsley, M., Sinthawanarong, K. Critical factors influencing construction productivity in Thailand. The journal of King Mongkut's University of Technology 2004 14(3), 1-6.

23. Olomolaiye, P.O., Wahab, K.A., Price, A.D.F. Problems influencing craftsmen's productivity in Nigeria. Building and environment 1987 22(4), 317-332. https://doi.org/10.1016/0360-1323(87)90024-2

24. Sutton, J., Kpentey, B. An enterprise map of Ghana. International Growth Centre 2012.

25. UNCTAD. World Investment Report 2011: Non-equity modes of international production and development. Geneva: United Nations 2011.

26. GIPC. GIPC quarterly report: First quarter (2010) investment report. Accra: Ghana Investment Promotion Centre 2010.

27. Pessiki, S., Prior, R., Sause, R. Slaughter, S. Review of existing precast concrete gravity load or framing systems. PCI Journal 199540 (2), 70-83.

28. Domel, A.W., Ghosh, S.K. Concrete Floor Systems: Guide To Estimating and Economizing, Portland Cement Association 1990.

29. Enshassi, A., Mohamed, S., Mustafa, Z.A., Mayer, P.E. Factors affecting labour productivity in building projects in the Gaza Strip. J Civ Eng Manag 2007 XIII(4), 245-254. Sugiharto A. Factors influencing construction productivity in the Indonesian context. J East Asia Soc Transp Stud 2003 4, 1557-1571.

30. Sugiharto A. Factors influencing construction productivity in the Indonesian context. J East Asia Soc Transp Stud 20034 , 1557-1571.

31. Talhouni, B.T. Measurement and analysis of construction labour productivity [dissertation]. Dundee: University of Dundee 1990.

32. Herbsman, Z., Ellis, R. Research of factors influencing construction productivity. Construction management and economics 1990 8(8), 49-61.

33. Montaser, N., Mahdi, I., Mahdi, H., Rashid, I.A. Factors Affecting Construction Labor Productivity for Construction of Pre-Stressed Concrete Bridges. International Journal of Construction Engineering and Management 2018 7(6): 193-206.

34. Jarkas, A.M., Al Balushi, R.A., Raveendranath, P.K. Determinants of construction labour productivity in Oman. International Journal of Construction Management 2015 15(4), 332-344. https://doi.org/10.1080/15623599.2015.1094849

35. Jarkas, A. Factors influencing labour productivity in Bahrain's construction industry. International Journal of Construction Management 2015 15(1): 94-108. https://doi.org/10.1080/15623599.2015.1012143

36. Tahir, M.A., Hashimhanif, S.Z.A., Hanif, A. Factors affecting labor productivity in building projects of Pakistan. Proceedings of the Seventh IIER International Conference, Singapore 2015.

37. Gundecha M. Study of factors affecting labor productivity at a building construction project in the USA: web survey [dissertation]. Fargo (ND): North Dakota State University 2012.

38. Omran, A., Hammad, M.S., Mamat, A.K.P. Factors affecting productivity in the Libyan construction projects: a case study. J Agr Resour Econ 2011 3, 7788.

39. Rivas, R.A., Borcherding, J.D., Gonzalez, V., Alarcon, L.F. Analysis of factors influencing productivity using craftsmen questionnaires: case study in a Chilean construction company. J Constr Eng M 2011 137, 312320.

40. Dai, J., Goodrum, P.M., Maloney, WF. Construction craft workers' perceptions of the factors affecting their productivity. J Constr Eng M 2009, 135, 217226.

41. Hayes, A.F., Montoya, A.K., Rockwood, N.J. The analysis of mechanisms and their contingencies: PROCESS versus structural equation modeling. Australasian Marketing Journal 2017 25(1), 76-81.

http://dx.doi.org/10.1016/j.ausmj.2017.02.001

42. Armstrong, A. Foley, P. Foundations for a learning organization: organization learning mechanisms. The Learning Organization 2003, 10(2), 74-82. https://doi.org/10.1108/09696470910462085

43. Ferketich, S. Focus on Psychometrics Aspects of Item Analysis. Research in Nursing E Health 1991 14, $165-168$. https://doi.org/10.1002/nur.4770140211 Makridakis, S., Hyndman, R. Forecasting Methods and Applications. Third Edition, John Wiley \& Sons, Inc 1998.

44. Gujarati, D., Gunasekar, S. Basic Econometrics. Fifth Edition, Tata McGraw Hill Education Private Limited 2012.

45. Jimoh, R., Oyewobi, L., Suleiman, S., Isa, S. Influence of supervision on labour productivity construction sites in Abuja-Nigeria. Independent journal of management $\mathcal{E}$ production 2017 8(1). http://doi.org/10.14807/ijmp.v8i1.523

46. Frimpong, J. A., Helleringer, S., Awoonor-Williams, J. K., Yeji, F., Phillips, J. F. Does supervision improve health worker productivity? Evidence from the Upper East Region of Ghana. Tropical Medicine \& International Health 2011 16, $1225-1233$.

47. Fischer, R. Productivity in the construction industry Unpublished, MSc thesis, University of Pretoria, Pretoria 2009.

48. Awan, A.G., Tahir, T. Impact of working environment on employee's productivity: A case study of Banks and Insurance Companies in Pakistan. European Journal of Business and Management 2015, 7(1). 
49. Jarkas, A., Bitar, C. Factors Affecting Construction Labor Productivity in Kuwait. J Constr Eng M 2012 138(7). https://doi.org/10.1061/(ASCE)CO.1943-7862.0000501

50. Nyoni, T., Bonga. An empirical investigation of factors affecting construction sector labour productivity in Zimbabwe. International Journal of Business and Management Invention 2016 5(8), 68-79.

51. Doloi, H. Analysis of pre-qualification criteria in contractor selection and their impacts on project success. Construction Management and Economics 2009 27(12), 1245-1263. https://doi.org/10.1080/01446190903394541 